\title{
APA ITU PATEN? SERTA CONTOH PADA PERUSAHAAN PRODUK SUZUKI
}

\author{
Fakhri Muslidar \\ 155100029 \\ Fakultas Komputer, 448757220 \\ Fakhrimuslidar.student@umitra.ac.id
}

\begin{abstract}
Paten merupakan suatu hak eksklusif yang diberikan oleh suatu Negara kepada penemu atas hasil penemuannya di bidang teknologi, yang untuk selama waktu tertentu melaksanakan sendiri Invensi atau penemuannya atau memberikan persetujuannya kepada pihak lain untuk melaksanakannya. (UU RI no. 14 tahun 2001).

Kata paten itu sendiri berasal dari bahasa inggris yaitu patent, yang sebenarnya pada awalnya berasal dari kata patere yang berarti membuka dan juga berasal dari istilah letters patent, yaitu surat keputusan yang dikeluarkan oleh suatu kerajaan yang memberikan hak eksklusif kepada individu dan pelaku bisnis tertentu. Dari definisi kata paten itu sendiri, konsep paten sebenarnya mendorong seorang inventor untuk membuka pengetahuan demi kemajuan masyarakat dan sebagai gantinya, inventor mendapat hak eksklusif selama periode tertentu.

Suzuki, sebuah merk perusahaan terkenal dengan berbagai hasil produksi yang sudah tidak diragukan lagi dan sudah mendunia ini ternya pula banyak melewati berbagai rintangan dan hambatan yang begitu pla jatuh bangun dialami seorang pemegang hak paten oleh produk ini. Yang pada awalnya saat itu Suzuki hanya menguasai sedikit pengetahuan tentang memproduksi mobil dan sepeda motor namun pada akhirnya ia optimis bahwa ia harus mempelajari suatu hal yang ia belum ketahui untuk menjadikannya besar, dan terbukti hingga saat ini Suzuki sangat mendunia dan sudah menghasilkan laba yang berlimpah. Hal yang mengagumkan adalah ide cemerlang dari pemilih paten produk tersebut dengan mencari referensi dari sesuatu yang sudah terkenal sebagai acuan bisnis barunya tersebut. Otomatis, langkah awal mereka untuk membuat motor \& mobil yang bagus dengan meniru mobil buatan pabrikan Eropa adalah sangat benar.
\end{abstract}

Kata Kunci : Paten, ekslusif, teknologi, invensi, dan inventor. 


\section{A. INTRODUCTION}

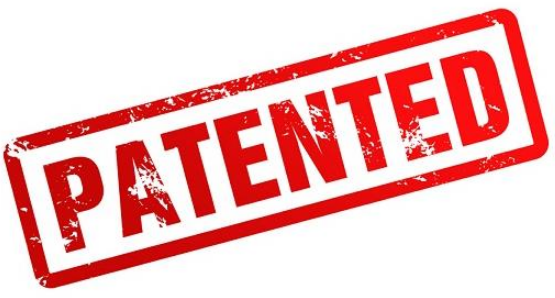

Paten merupakan suatu hak eksklusif yang diberikan oleh suatu Negara kepada penemu atas hasil penemuannya di bidang teknologi, yang untuk selama waktu tertentu melaksanakan sendiri Invensi atau penemuannya atau memberikan persetujuannya kepada pihak lain untuk melaksanakannya. (UU RI no. 14 tahun 2001).

Berikut merupakan 2 hal yang berkaitan dengan paten :

1. Invensi, invensi merupakan sebuah ide Inventor yang dituangkan ke dalam suatu kegiatan pemecahan masalah yang spesifik di bidang teknologi dapat berupa produk ataupun proses, atau penyempurnaan dan pengembangan produk atau proses.

(UU RI no. 14 tahun 2001, pasal 1, ayat 2).

2. Inventor, Inventor merupakan seorang yang secara sendiri atau beberapa orang yang secara bersama-sama melaksanakan ide yang dituangkan ke dalam kegiatan yang menghasilkan Invensi.
(UU RI no. 14 tahun 2001, pasal 1 , ayat 3 ).

Kata paten itu sendiri berasal dari bahasa inggris yaitu patent, yang sebenarnya pada awalnya berasal dari kata patere yang berarti membuka dan juga berasal dari istilah letters patent, yaitu surat keputusan yang dikeluarkan oleh suatu kerajaan yang memberikan hak eksklusif kepada individu dan pelaku bisnis tertentu.

Dari definisi kata paten itu sendiri, konsep paten sebenarnya mendorong seorang inventor untuk membuka pengetahuan demi kemajuan masyarakat dan sebagai gantinya, inventor mendapat hak eksklusif selama periode tertentu.

Subjek yang dapat dipatenkan :

Ada 3 kategori subjek yang dapat dipatenkan yaitu : mesin, proses, dan barang yang diproduksi atau ditemui oleh 1 orang atau lebih.

Di Indonesia, syarat hasil temuan yang akan dipatenkan adalah sesuatu temuan yang baru baru atau belum pernah diungkapkan atau ditemukan sebelumnya, mengandung langkah inventif (tidak dapat diduga sebelumnya), dan dapat diterapkan dalam industri. 
Jangka waktu perlindungan untuk paten biasanya adalah 20 tahun, sementara paten sederhana adalah 10 tahun. Paten tidak dapat diperpanjang. Untuk memastikan teknologi yang diteliti belum dipatenkan oleh pihak lain dan layak dipatenkan, dapat dilakukan penelusuran dokumen paten.

Berbicara mengenai paten, maka pada artikel kali ini saya akan membahas mengenai produk Suzuki yang sudah cukup terkenal dalam dunia penindustrian khususnya bisnis dalam bidang kemajuan teknologi. Berikut merupakan logo suzuki yang telah dipatenkan :

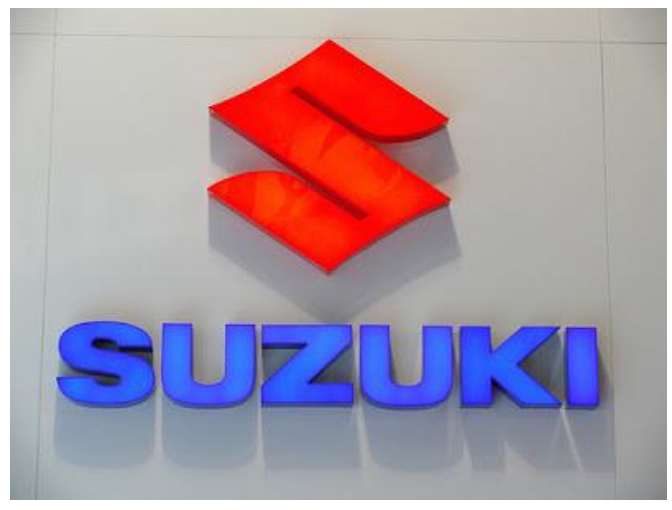

Terlepas dari hal itu, maka tentu saja paten akan dikaitkan dengan satu tokoh atau lebih sebagai pemegang hak kepemilikan dari produk tersebut. Pada perusahaan ini, nama yang akan saya kaitkan yaitu seorang tokoh besar yang bernama Michio Suzuki.

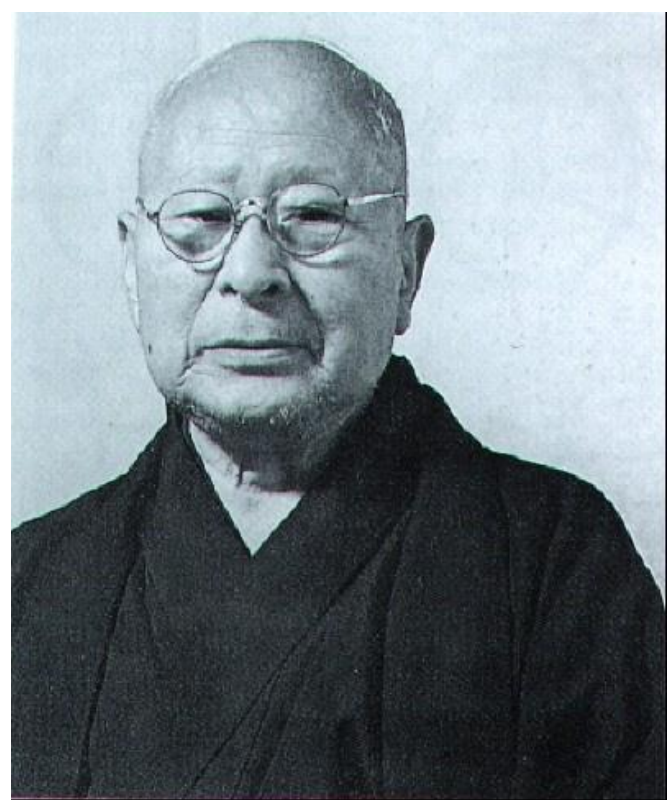

Michio Suzuki adalah Seorang Anak dari Petani Kapas Tradisional yang berasal dari Negara Jepang. Michio Suzuki yang dilahirkan pada 10 Februari 1887 di Kota Hamamatsu, Sebuah Kota yang dipenuhi dengan Industri Kain Tenun.

Awal mula Suzuki berkecimpung di Dunia Bisnis \& Produksi dimulai pada tahun 1909, Atau saat Suzuki sudah menginjak usia 22 tahun. Pada tahun tersebut, awal mulanya ia mencoba merancang sebuah alat tenun kayu yang dioperasikan dengan Pedal, dan mulai menjual produknya ke daerah sekitar Hamamatsu dengan Harga 50 Yen/Unit. Tanpa disangka, Bisnis nya berjalan baik, Produknya semakin diterima oleh para pengrajin kain tenun dan dikenal banyak orang. Atas dasar inilah, Suzuki kemudian mendirikan Suzuki

Loom 


\begin{abstract}
Works di Daerah Tenjin (Sekarang Kota Nakajima), Hamamatsu.

Sebelas tahun kemudian, setelah sukses menjulang bisnis nya dibidang mesin tenun kemudian tepatnya pada tahun 1920, Michio Suzuki memutuskan untuk memperkenalkan bisnis nya di bursa saham. Hal ini terpaksa dilakukan, Lantaran Michio Suzuki membutuhkan Modal untuk bisa Melanjutkan Inovasi dan penemuan yang terbaru mengingat kemajuan teknologi di Jepang pada saat itu semakin pesat, Melakukan Ekspansi Bisnisnya, Serta untuk memenuhi permintaan dari pasar yang semakin berkembang, Terutama permintaan ekspor ke Mancanegara.
\end{abstract}

Atas dasar Inilah, Michio Suzuki kemudian mendirikan Suzuki Loom Manufacturing Company, Inc (Suzuki Jidosha Kogyo), Pada 15 Maret 1920. Perusahaan ini dipimpin oleh 72 pemegang saham, Yang masing-masing memberikan Modal Luar Biasa bagi Michio Suzuki, Sehingga perusahaan ini berkebang pesat hanya dalam jangka 2 tahun.

Perusahaan ini kembali bertambah maju, Seiring dengan Ekspansi Mesin Tenun nya ke Berbagai Negara di Asia Tenggara. Sayangnya, karena Perang Besar dengan China pada akhir tahun 1930an, Kondisi Ekonomi Jepang menjadi sangat lemah, Serta Permintaan mesin tenun semakin berkurang. Namun, hal itu tidak menyurutkan semangat dari seorang Suzuki untuk menciptakan suatu hal yang baru dan dibutuhkan oleh masyarakat luas. Suzuki kemudian memulai langkahnya di bidang Automobile (Roda 4). Didasari atas pemikirannya tentang 20.000 kendaraan diimpor Jepang tiap tahunnya, Angka ini belum bisa memuaskan permintaan pasar akan kendaraan kelas ringan yang murah namun tidak murahan Michio Suzuki pun melihat celah pasar ini dan memulai langkah pertamanya di Bidang Otomotif.

Benar saja, saat itu Tim riset Suzuki membeli sebuah Mobil Austin Seven dari Negara Inggris, Mobil ini kemudian dibongkar dan dipelajari oleh tim Suzuki tersebut. Setelah beberapa bulan kemudian berdasarkan pengalaman mereka membuat Produk Mesin Tenun, Suzuki telah mampu membuat replika dari mobil 737 cc buatan inggris tsb. Itulah awal mula Suzuki menciptakan penemuannya dan dikenal hingga sekarang dengan nama pemilik paten itu sendiri yaitu SUZUKI. Saat ini Suzuki sudah berkembang dan sudah memiliki banyak cabang produk teknologi. 


\section{B. CONCLUSION}

Kesimpulannya yaitu, pada dasarnya paten atau hak paten merupakan suatu hal yang ada, jika terdappat suatu penemuan oleh 1 orang atau lebih yang membuat itu menjadi hak kepemilikan atau hak penemuan darinya yang dikeluarkan dalam bentuk industri atau bisnis.

Sesuai dengan asal mula kata dari paten itu sendiri yaitu patent, yang sebenarnya pada awalnya berasal dari kata patere yang berarti membuka dan juga berasal dari istilah letters patent, yaitu surat keputusan yang dikeluarkan oleh suatu kerajaan yang memberikan hak eksklusif kepada individu dan pelaku bisnis tertentu.

Suzuki, sebuah merk perusahaan terkenal dengan berbagai hasil produksi yang sudah tidak diragukan lagi dan sudah mendunia ini ternya pula banyak melewati berbagai rintangan dan hambatan yang begitu pla jatuh bangun dialami seorang pemegang hak paten oleh produk ini. Yang pada awalnya saat itu Suzuki hanya menguasai sedikit pengetahuan tentang memproduksi mobil dan sepeda motor namun pada akhirnya ia optimis bahwa ia harus mempelajari suatu hal yang ia belum ketahui untuk menjadikannya besar, dan terbukti hingga saat ini Suzuki sangat mendunia dan sudah menghasilkan laba yang berlimpah. Hal yang mengagumkan adalah ide cemerlang dari pemilih paten produk tersebut dengan mencari referensi dari sesuatu yang sudah terkenal sebagai acuan bisnis barunya tersebut. Otomatis, langkah awal mereka untuk membuat motor \& mobil yang bagus dengan meniru mobil buatan pabrikan Eropa adalah sangat benar.

\section{ACKNOWLEDGEMENT University Of Indonesia University Of Mitra Indonesia Telkom University University Of Mellbourne Saitama University}

\section{REFERENCE (Based ISO 690 )}

A. S. Putra And O. M. Febriani, "Knowledge Management Online Application In Pdam Lampung Province," In Prosiding International Conference On Information Technology And Business (Icitb), 2018, Pp. 181-187.

[2] A. S. Putra, O. M. Febriani, And B. Bachry, "Implementasi Genetic Fuzzy System Untuk Mengidentifikasi Hasil Curian Kendaraan Bermotor Di Polda Lampung," J. Sist. Inf. Dan Manaj. Basis Data, Vol. 1, No. 1, Pp. 21-30, 2018.

[3] O. M. Febriani And A. S. Putra, "Sistem Informasi Monitoring Inventori Barang Pada Balai 
Riset Standardisasi Industri Bandar Lampung," J. Inform., Vol. 13, No. 1, Pp. 90-98, 2014.

[4] Putra, Arie Setya. "2018 Artikel Struktur Data, Audit Dan Jaringan Komputer." (2018).

[5] Putra, A. S. (2018, July 17). Paperplain Fundamental Create Application With Borland Delphi 7.0 University Of Mitra Indonesia. Retrieved From Osf.Io/Pbrn9.

\section{E. REFERENCE(Based APA )}

Putra, A. S., Aryanti, D. R., \& Hartati, I. (2018, November). Metode SAW (Simple Additive Weighting) sebagai Sistem Pendukung Keputusan Guru Berprestasi (Studi Kasus: SMK Global Surya). In Prosiding Seminar Nasional Darmajaya (Vol. 1, No. 1, pp. 85-97).

Sari, D. P., Febriani, O. M., \& Putra, A. S. (2018, November). Perancangan Sistem Informasi SDM Berprestasi pada SD Global Surya. In Prosiding Seminar Nasional Darmajaya (Vol. 1, No. 1, pp. 289-294).

Putra, A. S. (2018). Paperplain: Execution Fundamental Create Application With Borland Delphi 7.0 University Of Mitra Indonesia.

Putra, A. S., Sukri, H., \& Zuhri, K. Sistem Monitoring Realtime Jaringan Irigasi Desa (JIDES) Dengan Konsep Jaringan Sensor Nirkabel. IJEIS (Indonesian Journal of Electronics and Instrumentation Systems), 8(2), 221232.
Darmawan, A., Yuliawati, D., Marcella, O., \& Firmandala, R. (2016). Sistem Absensi dan Pelaporan Berbasis Fingerprint dan SMS Gateway. EXPLORE, 7(1).

Febriani, O. M., Wahyuni, T., \& Yusuf, S. (2017). DESIGN OF WEBSITE-BASED INFORMATION SYSTEM FOR EDOCUMENT ADMINISTRASI IN THE COMMUNITY SERVICE UNIT (A Case Study at Rajabasa District). INTERNATIONAL JOURNAL OF COMPUTERS \& TECHNOLOGY, 16(7), 7010-7020.

Febriani, O. M., \& Wahyuni, T. (2017, October). PERANCANGAN SISTEM E-DOCUMENT ADMINISTRASI LOGBOOK PENELITIAN PADA UNIT LAYANAN DI BANDAR LAMPUNG. In Prosiding Seminar Nasional Darmajaya (Vol. 1, No. 1, pp. 187-194).

Febriani, O. M., \& Permadi, A. B. (2017). Implementasi Sistem Aplikasi Data Bimbingan dan Pelanggaran Siswa pada Sekolah Menengah Atas di Lampung Tengah dengan Metode Analisis dan Desain Sistem Terdistribusi (SSAD). EXPERT, 7(1).

Febriani, O. M., \& Ambarwati, L. (2015). PERANCANGAN APLIKASI PENGOLAHAN DATA PENJUALAN UKM KELANTING KHAS TELO DESA SIDOHARJO KECAMATAN JATI AGUNG KABUPATEN LAMPUNG SELATAN. Jurnal Teknologi Informasi dan Bisnis Pengabdian Masyarakat Darmajaya, 1(1), 77-95. 
Febriani, O. M. (2015). Rancang Bangun Aplikasi Ecommercemenggunakan Freewebstore pada UKM Kelanting di Desa Sidoharjo Lampung Selatan. Prosiding Sembistek 2014, 1(02), 446-458. 